Plutonium and Uranium Atom Ratios

and Activity Levels in

Cochiti Lake Bottom Sediments

Provided by Pueblo de Cochiti

B. M. Gallaher ${ }^{1}$

D. W. Efurd ${ }^{2}$

D. J. Rokop ${ }^{3}$

T. M. Benjamin ${ }^{2}$ 



\section{DISCLAIMER}

This report was prepared as an account of work sponsored by an agency of the United States Government. Neither the United States Government nor any agency thereof, nor any of their employees, make any warranty, express or implied, or assumes any legal liability or responsibility for the accuracy, completeness, or usefulness of any information, apparatus, product, or process disclosed, or represents that its use would not infringe privately owned rights. Reference herein to any specific commercial product, process, or service by trade name, trademark, manufacturer, or otherwise does not necessarily constitute or imply its endorsement, recommendation, or favoring by the United States Government or any agency thereof. The views and opinions of authors expressed herein do not necessarily state or reflect those of the United States Government or any agency thereof. 


\section{DISCLAIMER}

Portions of this document may be illegible in electronic image products. Images are produced from the best available original document. 


\section{Contents}

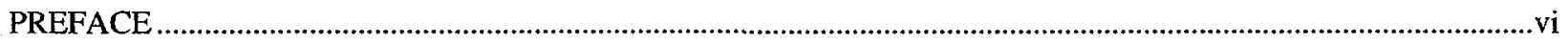

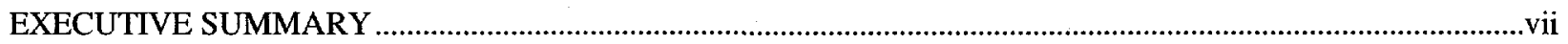

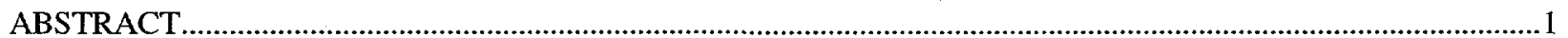

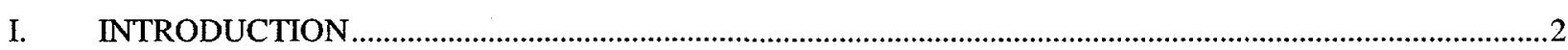

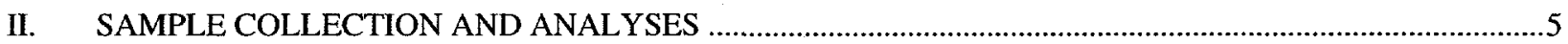

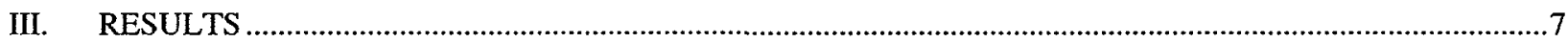

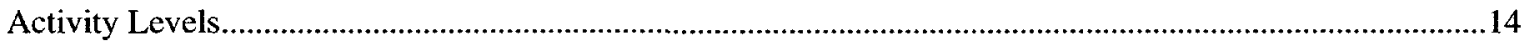

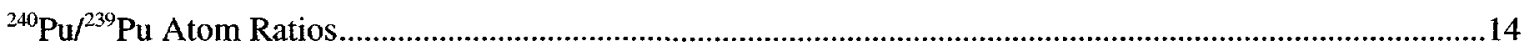

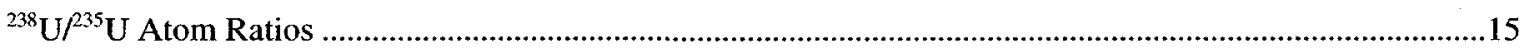

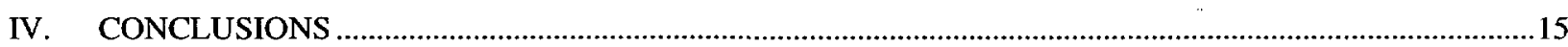

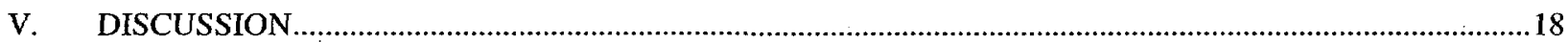

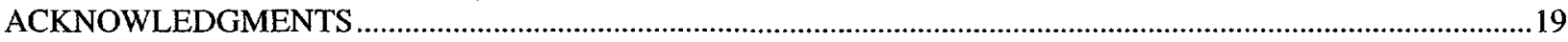

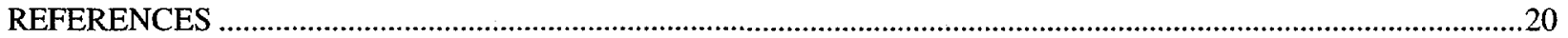

List of Tables

1. Plutonium Atom Abundances and ${ }^{240} \mathrm{Pu} /{ }^{239} \mathrm{Pu}$ Isotope Ratios in Cochiti Reservoir Bottom Sediments.............9

2. Plutonium Isotope Concentrations in Cochiti Reservoir Bottom Sediments ................................................10

3. Uranium Isotope Atom Ratios and Mass Concentrations in Cochiti Reservoir Bottom Sediments .................11

4. Uranium Atom Abundances in Cochiti Reservoir Bottom Sediments .......................................................12

5. Uranium Isotope Concentrations in Cochiti Reservoir Bottom Sediments ..................................................13

List of Figures

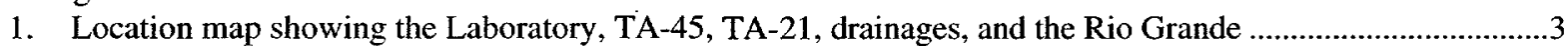

2. Location of Los Alamos, Cochiti Lake, and other reservoirs within the Rio Grande drainage basin................4

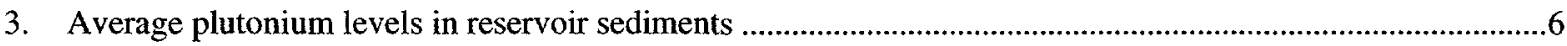

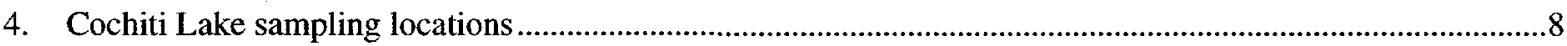

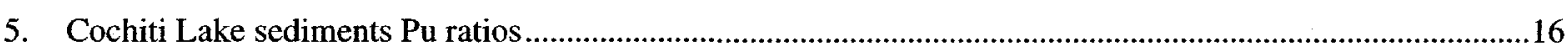

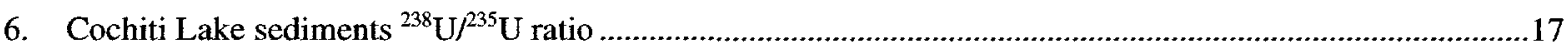




\section{PREFACE}

Cooperative Agreements were signed in November 1994 between the Los Alamos National Laboratory (Laboratory) and three Indian Pueblos near the Laboratory: San Ildefonso, Cochiti, and Jemez. Implementation of the Agreements began in 1995. A separate agreement was signed between the Laboratory and Santa Clara Pueblo in 1996. The Cooperative Agreements provide a formal relationship between the Laboratory and these Indian Pueblos to address environmental, cultural, educational, employment, and socioeconomic issues and initiatives. The general objectives of the Cooperative Agreements are to ensure mutually beneficial resolution for issues of concern and to lay groundwork for successful long-term relations between the Indian Pueblos and the Laboratory.

An issue of concern to both the Pueblo de Cochiti and the Laboratory is possible environmental contamination of Cochiti Lake, located approximately $8 \mathrm{~km}$ downstream of the Laboratory boundary. The work described in this report was designed by the Laboratory to help address this area of concern.

The Pueblo de Cochiti is currently managing a broad investigation of the water and sediment quality of the lake. The investigation, called the Cochiti Lake Study, is a project supported by a U.S. Department of Energy/Pueblo de Cochiti Agreement and is designed and managed by the Cochiti Environmental Protection Office (CEPO). This project will evaluate the impact of Laboratory operations on the quality of lacustrine sediments in the Rio Grande above Cochiti Lake and in Cochiti Lake. The CEPO and the U.S. Geological Survey conducted a Phase I sampling of lacustrine sediments at selected locations, and splits of these samples were provided to the Laboratory's Water Quality and Hydrology Group (ESH-18) for analyses by thermal ionization mass spectrometry. The results of analyses presented herein are acceptable to the CEPO; however, the interpretation contained here is by the Laboratory. The CEPO will continue the Cochiti Lake Study and provide an independent interpretation at its conclusion. 


\section{EXECUTIVE SUMMARY}

Using a new analytical "fingerprinting" technique, we have confirmed in sediments collected from Cochiti Lake the presence of plutonium from the Los Alamos National Laboratory (Laboratory). The new data shows that approximately one-half of the plutonium is derived from Laboratory sources. The remaining half comes from erosion of soils in northern New Mexico that contain plutonium deposited on the landscape from worldwide fallout.

Plutonium and uranium have been released into canyons draining the Los Alamos National Laboratory since the Manhattan Project. In Los Alamos Canyon, these contaminants have been carried by flood flows several tens of kilometers downstream into the Rio Grande. The plutonium and uranium were introduced into the canyon during the 1940s and 1950 s by discharging liquid effluents from some of the early research facilities at the Laboratory.

This study employs a new analytical "fingerprinting" technique to better quantify the impacts of these activities on Cochiti Lake, the first reservoir downstream of the Laboratory. This specialized analytical method allows us to discern Laboratory-derived plutonium and uranium from that derived from worldwide fallout or from natural sources. The Pueblo de Cochiti provided to the Laboratory a total of 15 sediment samples collected from the bottom of Cochiti Lake for this analysis.

The analytical results confirm the presence of Laboratory-derived plutonium in the lake sediments; Laboratory-derived uranium, however, was not identifiable. Eight of the nine segments of a vertical core taken near the dam showed a clear "fingerprint" of Laboratory plutonium. Only the lower core segment showed no indication of Laboratory plutonium. All of the samples of the upper few inches of the lake sediments showed little or no Laboratory plutonium. We calculate that approximately one-half of the plutonium at the core site is derived from the Laboratory and the other half from worldwide fallout. Previous studies had estimated the Laboratory contribution to the Rio Grande drainage system to be lower-approximately 10 percent. The collected data suggest that the sediments most recently deposited in Cochiti Lake, seen at the surface of the sediment pile, are less contaminated than those at depth.

In terms of radioactivity, results from earlier Laboratory monitoring efforts show that the plutonium levels in Cochiti Lake sediments are slightly higher, but of the same magnitude, than in other upstream reservoirs on the Rio Grande and the Rio Chama. The greatest difference is seen with Abiquiu Reservoir on the Rio Chama; plutonium levels in Cochiti Lake are approximately 3.5 times higher. These initial fingerprinting results suggest that much of the difference can be attributed to Laboratory sources.

While we can identify a Laboratory contribution in the lake sediments, the overall plutonium content (one-tenth of a trillionth of a gram of plutonium per gram of soil) is 1000 times below levels that would generally trigger cleanup. The net increase in radioactivity over background would be difficult to recognize using conventional analytical techniques. 


\title{
Plutonium and Uranium Atom Ratios and Activity Levels in Cochiti Lake Bottom Sediments Provided by Pueblo de Cochiti
}

by

\author{
B. M. Gallaher, D.W. Efurd, D. J. Rokop, T. M. Benjamin
}

\begin{abstract}
Historical operations at the Los Alamos National Laboratory have contaminated stream sediments with plutonium and other radionuclides. A small portion of these contaminated sediments has been carried by floods into the Rio Grande drainage system, eventually to be trapped by Cochiti Lake located on Pueblo de Cochiti lands approximately $8 \mathrm{~km}$ downstream of the Laboratory. In this study, lake bottom sediment samples provided by the Pueblo de Cochiti were analyzed by thermal ionization mass spectrometry to determine plutonium and uranium activity levels and isotopic atom ratios. This specialized analytical method allows us to take isotopic fingerprints of radionuclides found in the sediment and to determine how much plutonium and uranium came from the Laboratory and how much was deposited by worldwide fallout or is natural. Two distinct types of samples were processed: segments of a continuous vertical core of the entire accumulated sediment sequence and other samples from across the lake bottom at the water/sediment interface. Based on measurement of the ${ }^{240} \mathrm{Pu} /{ }^{239} \mathrm{Pu}$ atom ratio, Laboratory-derived plutonium is present in eight of nine samples at the core site. On a depth-weighted basis, approximately one-half of the ${ }^{239} \mathrm{Pu}$ and ${ }^{240} \mathrm{Pu}$ came from early operations at the Laboratory; the remaining plutonium came from fallout dispersed by above-ground nuclear tests. In contrast to the core site, the samples from the other locations showed little or no evidence of Laboratory-derived plutonium, with more than 90 percent of the plutonium attibutable to fallout. The overall amount of plutonium in all the samples is of the same magnitude as other reservoirs in the region. The net increase in plutonium over upstream reservoirs unaffected by Laboratory activities is a maximum of $0.014 \mathrm{pCi} / \mathrm{g}$ or 3.5 times. All of the samples reflect natural uranium compositions. Laboratory-derived uranium is not identifiable, presumably because the sediment contains abundant natural uranium that obscures the Laboratory signatures. Although Los Alamos legacy activities have contributed radioactivity to Cochiti Lake, there is no evidence of Laboratory-produced radionuclides entering the food chain or leaching into the water. Additional core samples are expected to be collected by the Pueblo de Cochiti to reduce uncertainty in contaminant inventory and risk estimates.
\end{abstract}




\section{INTRODUCTION}

Research and development activities at the Los Alamos National Laboratory (Laboratory) have resulted in the release of plutonium and other radionuclides into canyons draining the Laboratory. The most significant contaminant sources were former Technical Area (TA) 45, where radioactive effluent was discharged between 1944 and 1964 in Acid Canyon, a tributary to Pueblo Canyon, and an outfall at TA-21, where radioactive effluent was discharged between 1956 and 1985 into DP Canyon, a tributary to upper Los Alamos Canyon (Figure 1). An estimated 2 to 12 grams of plutonium were released into the Los Alamos Canyon drainage system. (USDOE 1981, Graf 1996, LANL 1998). Most of the plutonium quickly became adsorbed to the sediments in the stream channels.

In the decades since, floods have carried a small portion of this contaminant inventory more than $20 \mathrm{~km}$ downstream in the Pueblo/Los Alamos Canyon drainage system, across the Laboratory boundary and San Ildefonso Pueblo lands, and into the Rio Grande. Much of the contaminant inventory has been dispersed laterally away from the stream channel and deposited on floodplains. Long-term monitoring by the Laboratory indicates that mean plutonium concentrations in the channel sediments decline from a maximum of approximately $10,000 \mathrm{fCi} / \mathrm{g}$ near the discharge areas to 100 $\mathrm{fCi} / \mathrm{g}$ at the confluence of the canyon system and the Rio Grande. The downstream decline in concentrations is presumably due to the mixing with cleaner stream sediments. Los Alamos Canyon sediments in turn are subsequently mixed with sediments (and worldwide fallout-related radionuclides) carried by the Rio Grande.

Cochiti Lake since 1973 has served to trap most of the Rio Grande stream sediments carried from Los Alamos Canyon and from northern New Mexico. The lake is located approximately $8 \mathrm{~km}$ downstream of the Laboratory's southern boundary (Figure 1). Water, sediment, and fish samples from the Rio Grande and Cochiti Lake have been tested for more than 15 years by the Laboratory's Environmental Surveillance Program.

The analytical results obtained from these monitoring activities show low but measurable levels of radionuclides in both the river and lake sediments (ESP 1997). The collective risk posed by these radionuclides, however, is relatively small. There is no evidence of Laboratory-produced radionuclides entering the food chain within Cochiti Lake (Fresquez et al. 1994, 1995). The calculated radiation doses to downstream users of the Rio Grande that are attributable to Laboratory discharges are only a small fraction (on the order of $1 \%$ ) of the dose from natural background and worldwide fallout radiation (Ferenbaugh et al. 1994, USDOE 1981). Preliminary dose calculations for Cochiti Lake users show similar conclusions (McLin, personal communication).

Plutonium levels in Cochiti Lake sediments are typically within the range found in soils affected only by worldwide fallout (Purtymun et al. 1990). This makes it difficult to distinguish the Los Alamos contribution from background. In most of the sediment samples the net increase in radioactivity over background levels would be difficult to recognize using conventional analytical techniques. (To increase the resolution of these conventional radiological counting techniques and to allow for measurement of contamination in Cochiti Lake, the Laboratory's Environmental Surveillance Program since 1979 has 


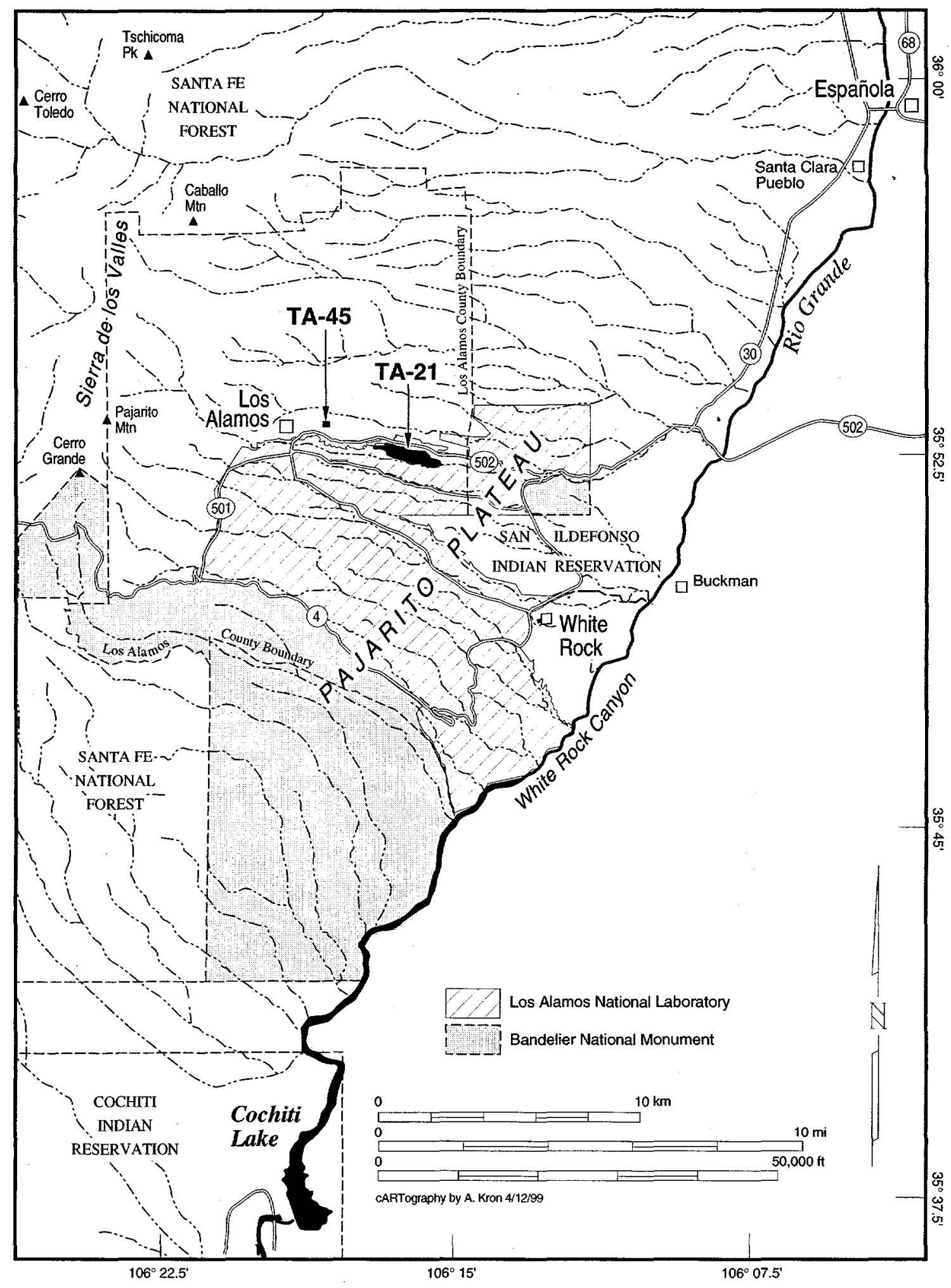

Figure 1. Location map showing the Laboratory, TA-45, TA-21, drainages, and the Rio Grande. 


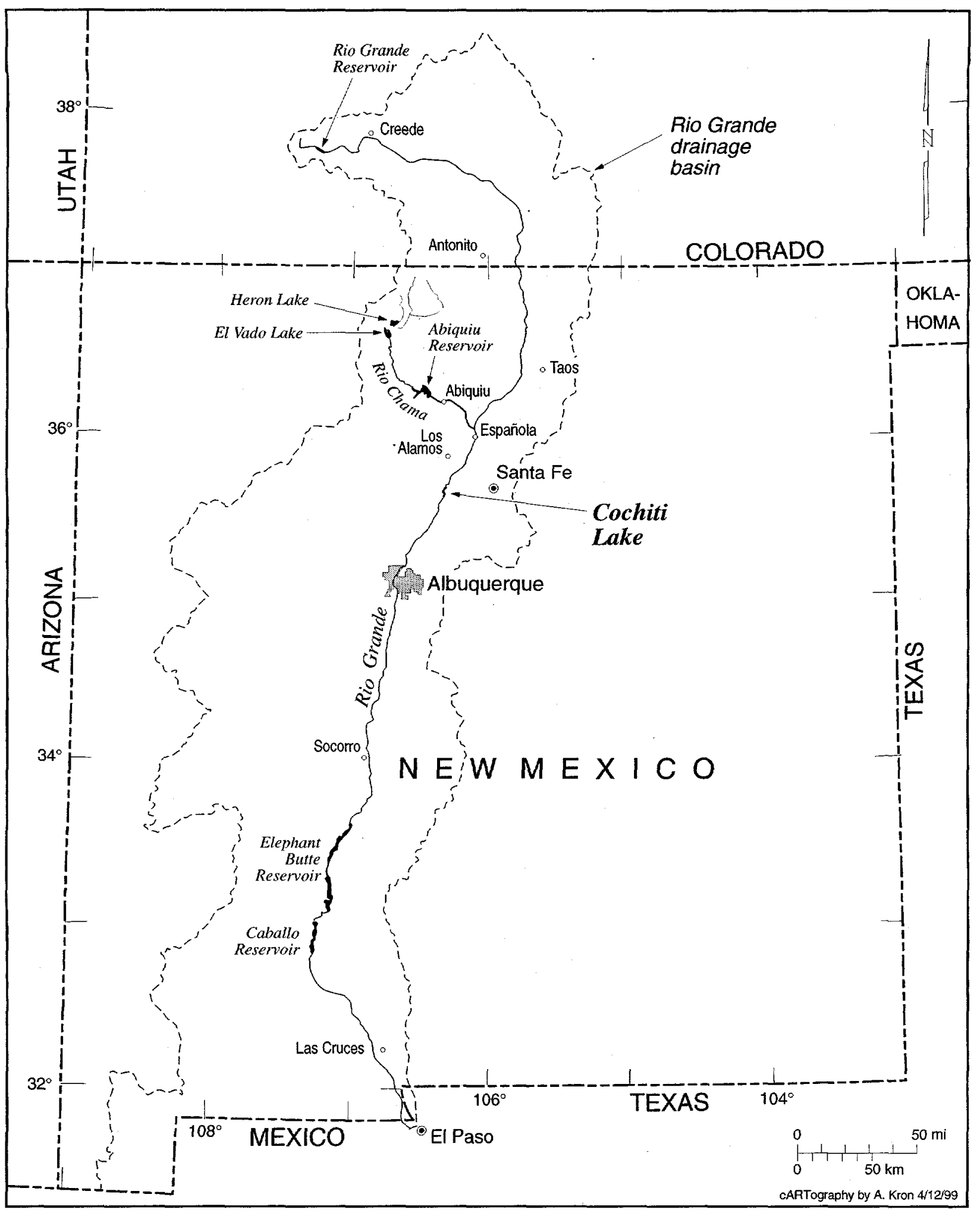

Figure 2. Location of Los Alamos, Cochiti Lake, and other reservoirs within the Rio Grande drainage basin. 
analyzed 1-kg size lake sediment samples, which are 10 times larger than normal.

In a comprehensive geologically based study, Graf (1994) estimated that 90 percent of the plutonium moving in the northern Rio Grande drainage system (Figure 2) was from worldwide atmospheric fallout. The remaining 10 percent was attributed to releases from the Laboratory.

As shown in Figure 3, long-term average plutonium levels in Cochiti Lake sediments are slightly higher than other reservoirs along the Rio Grande that have been impacted only by worldwide fallout (Rio Grande and Elephant Butte Reservoirs). In contrast, the Cochiti Lake plutonium levels are elevated by as much as $14 \mathrm{fCi} / \mathrm{g}$ (3.5 times) when compared with reservoirs on the Rio Chama (McLin, personal communication). Underscoring the trace levels, Cochiti Lake sediments ${ }^{239+240} \mathrm{Pu}$ levels are approximately 1000 times lower than the Screening Action Levels used by the Laboratory's Environmental Restoration Project as an initial check on whether a contaminant level warrants further study or remedial action (ER 1997). Nonetheless, the Cochiti Environmental Protection Office (CEPO) will continue the investigations of Cochiti Lake because widescale lake bottom sampling is incomplete. There is a particular need to develop representative vertical contaminant profiles across the lake through core-barrel sediment retrieval and analyses.

At low concentrations, standard quantitative measurements of plutonium and uranium (respectively, alpha pulse height spectrometry and chemical methods) are unable to distinguish Laboratory-derived components in environmental samples from background levels of these elements. Both plutonium and uranium are ubiquitous in the surface environment, and their presence at low concentrations cannot be exclusively related to a single source such as the Laboratory. Uranium is abundant naturally in soils and waters, and plutonium has been deposited worldwide via global fallout from atmospheric testing of nuclear devices.

In this study, we employ a specialized mass spectrometry analytical method developed at the Laboratory to further quantify the Laboratory's contribution of plutonium and uranium to Cochiti Lake bottom sediments. The "fingerprinting" of plutonium and uranium by measuring the isotopic composition by mass spectrometry is capable of distinguishing and quantifying the contributions of the different sources of these radionuclides in a single sample (Efurd et al. 1994, 1995). The isotopic composition of an environmental sample is determined and compared against the known compositions for Laboratory sources and for worldwide fallout. For these specialized fingerprinting analyses, the CEPO provided samples of lake bottom sediments from Cochiti Lake to the Laboratory. The CEPO, supported by the U.S.Geological Survey (USGS), collected the samples as part of a larger water and sediment quality investigation of Cochiti Lake.

\section{SAMPLE COLLECTION AND ANALYSES}

Sample collection was conducted by the Pueblo de Cochiti in accordance with the methods presented in Van Metre and Callender (1997). Two different types of lake bottom sediment samples were obtained: (1) surficial samples at the water/sediment interface and (2) samples from a core of the deeper accumulated sediments. Surficial bottom sediments were collected at seven locations across the lake bottom using a box core sampler. Typically, this sampler collects the top three $\mathrm{cm}$ of lake 


\section{Figure 3}

Average Plutonium in Reservoir Sediments

(mean + 1 standard deviation)

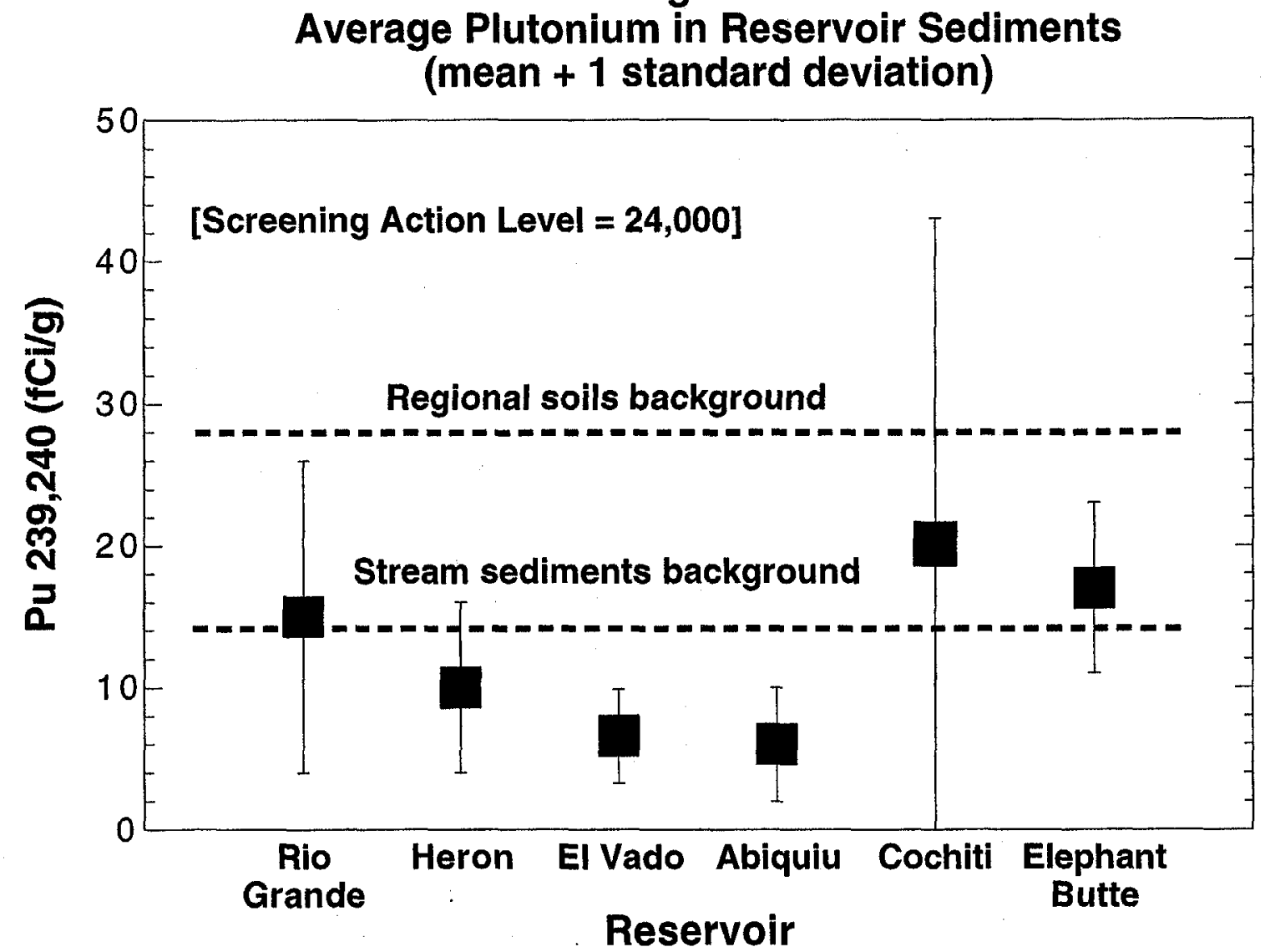


bottom sediment. At one location near the dam, deeper lake bottom sediments were sampled using a gravity corer to a depth of $156 \mathrm{~cm}$. The entire vertical sequence of accumulated lake sediments to the prereservoir land surface was sampled with the gravity corer. The core was extruded vertically and $13-\mathrm{cm}$ slices removed for chemical analyses. Pueblo de Cochiti sample locations are shown in Figure 4. Surficial samples were collected at the locations labeled with a letter-number combination, e.g., B1, R1. The vertical core was collected $150 \mathrm{~m}$ from the dam, and is labeled as Core Site. Also displayed in Figure 4 are locations for the Laboratory's Environmental Surveillance Program routine surficial sediment sampling, displayed as Upper, Middle, and Lower.

Pueblo de Cochiti samples collected for this study were split by the USGS at Austin, Texas, and submitted to the Los Alamos Clean Chemistry and Mass Spectrometry Laboratory for thermal ionization mass spectrometric (TIMS) analyses. All of the actinide activity levels and the atom ratios reported in this report were derived from the TIMS analyses. The procedures for TIMS analyses of uranium and plutonium were developed by the Mass Spectrometry Laboratory and are described in detail in Efurd et al. (1993a). The TIMS procedures are briefly summarized here.

TIMS sample preparation and mass spectrometry are both performed in class100 clean rooms specifically designed for ultra-low-level environmental actinide analyses. During the sample preparation, sediment samples initially are digested with ultra-pure acids. Sediments are then traced with precisely known amounts of reference standards, separated into elements by anion exchange chromatography, and electroplated on mass spectrometry filaments to produce an ionization source for TIMS analysis. The filament is then inserted into a thermal ionization mass spectrometer that measures the relative abundance of the isotopes of interest compared with the reference standards.

The TIMS procedure allows for the quantification of the isotopic composition of the plutonium in the sample, for example, the number of atoms of the isotope ${ }^{240} \mathrm{Pu}$ and of the isotope ${ }^{239} \mathrm{Pu}$ in a gram of sample. Measurement of the ${ }^{240} \mathrm{Pu} /{ }^{239} \mathrm{Pu}$ atom ratio in samples can be used to distinguish the global fallout component from the Laboratory component(s) based on knowledge of the isotopic composition of each. The following uranium isotopes are determined: ${ }^{234} \mathrm{U},{ }^{235} \mathrm{U},{ }^{236} \mathrm{U}$, and ${ }^{238} \mathrm{U}$. The ${ }^{238} \mathrm{U} /{ }^{235} \mathrm{U}$ atom ratio can be used to distinguish the naturally occurring uranium from anthropogenically produced components, i.e., enriched uranium and/or depleted uranium. The enriched and depleted forms of uranium result from the processing of natural uranium to selectively increase (or decrease) the abundance of ${ }^{235} \mathrm{U}$ relative to ${ }^{238} \mathrm{U}$. The atom ratio of ${ }^{238} U$ to ${ }^{235} U$ in naturally occurring uranium is a constant 137.8 (Efurd et al. 1993b). Enriched uranium may have an atom ratio of ${ }^{238} \mathrm{U}$ to ${ }^{235} \mathrm{U}$ lower than 0.06 , while in depleted uranium it may exceed 500. The ${ }^{236} \mathrm{U}$ isotope does not exist in nature, and its presence unambiguously indicates an anthropogenic component. The ${ }^{236} \mathrm{U}$ isotope is formed through exposure of ${ }^{235} \mathrm{U}$ to a neutron source, such as a reactor.

\section{RESULTS}

Tables 1 through 5 present the results of the analyses of the 16 sediment samples from Cochiti Lake. The sample numbers are the alphanumeric sequences used by the Mass Spectrometry Laboratory personnel to uniquely identify each sample. The atom ratios were measured by TIMS. The standard deviations of the atom ratios are at the 


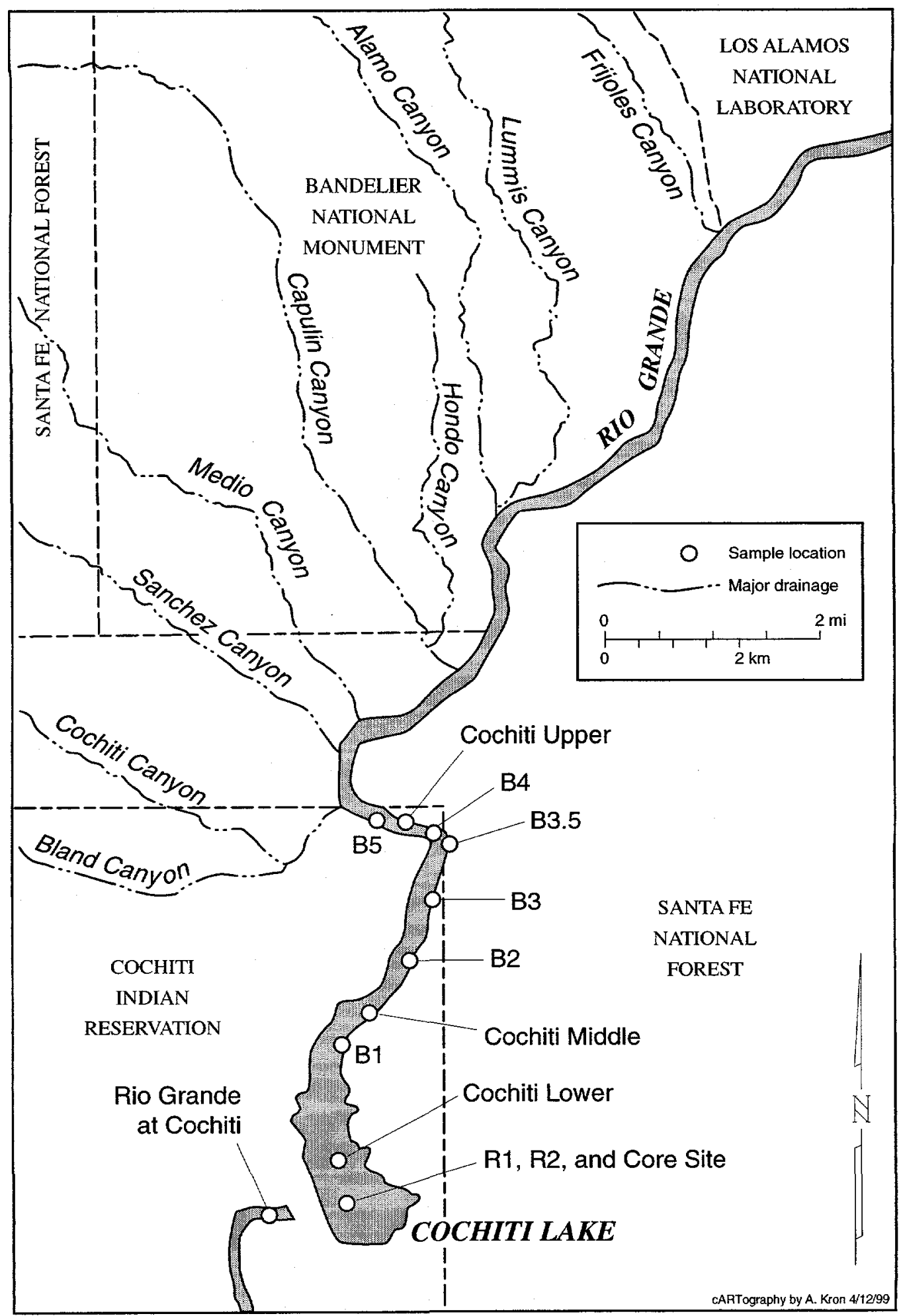

Figure 4. Cochiti Lake sampling locations. 
Table 1. Plutonium Atom Abundances and ${ }^{240} \mathrm{Pu} /{ }^{239} \mathrm{Pu}$ Isotope Ratios in Cochiti Reservoir Bottom Sediments

\begin{tabular}{|c|c|c|c|c|c|c|c|c|c|c|c|c|}
\hline \multirow[b]{2}{*}{ Sample } & \multirow{2}{*}{$\begin{array}{c}\text { Mass } \\
\text { Spec. } \\
\text { Samp. } \\
\text { No. }\end{array}$} & \multirow[b]{2}{*}{$\begin{array}{c}\text { Samp. } \\
\text { Size } \\
\text { gm }\end{array}$} & \multicolumn{2}{|c|}{ Pu 239} & \multicolumn{2}{|c|}{ Pu 240} & \multicolumn{2}{|c|}{ Pu 241} & \multicolumn{2}{|c|}{$\begin{array}{c}\text { Total Pu } \\
239+240+241 \\
\end{array}$} & \multicolumn{2}{|c|}{ Atom Ratio } \\
\hline & & & $\begin{array}{l}\text { Atoms } \\
\text { lgm }\end{array}$ & Uncert. \% & $\begin{array}{l}\text { Atoms } \\
\text { lgm }\end{array}$ & Uncert. \% & $\begin{array}{l}\text { Atoms } \\
\text { /gm }\end{array}$ & Uncert. \% & $\begin{array}{c}\text { Total } \\
\text { Atoms/gm }\end{array}$ & Uncert. \% & ${ }^{240} \mathrm{Pu} / l^{239} \mathrm{Pu}$ & Uncert. \% \\
\hline \multicolumn{13}{|l|}{$\begin{array}{r}\text { Core Site } \\
\text { COC \#3 }\end{array}$} \\
\hline $\begin{array}{l}\text { R11\&R12 } \\
\text { (Surface) }\end{array}$ & 13387 & 40.74 & $5.27 E+08$ & 0.40 & $7.69 \mathrm{E}+07$ & 0.66 & & & $6.04 \mathrm{E}+08$ & 0.36 & 0.146 & 0.78 \\
\hline $0-26 \mathrm{~cm}$ & 13384 & 21.62 & $4.45 E+08$ & 0.51 & $4.68 E+07$ & 2.43 & & & $4.92 E+08$ & 0.52 & 0.105 & 2.51 \\
\hline $26-52 \mathrm{~cm}$ & 13385 & 40.60 & $5 E+08$ & 0.39 & $4.22 \mathrm{E}+07$ & 1.46 & & & $5.42 E+08$ & 0.38 & 0.084 & 1.53 \\
\hline $52-78 \mathrm{~cm}$ & 13386 & 42.69 & 1.63E+09 & 0.18 & $6.33 E+07$ & 1.32 & & & $1.69 E+09$ & 0.18 & 0.039 & 1.34 \\
\hline $78-91 \mathrm{~cm}$ & 13350 & 24.64 & $1.01 E+09$ & 0.68 & $7.76 \mathrm{E}+07$ & 2.32 & $1.81 \mathrm{E}+06$ & 11.51 & $1.09 \mathrm{E}+09$ & 0.65 & 0.076 & 2.43 \\
\hline $91-104 \mathrm{~cm}$ & 13388 & 31.11 & $8.89 E+08$ & 0.41 & $6.09 \mathrm{E}+07$ & 1.60 & & & $9.50 \mathrm{E}+08$ & 0.39 & 0.068 & 1.66 \\
\hline $104-117 \mathrm{~cm}$ & 13351 & 36.24 & $8.58 E+08$ & 0.81 & $6.65 \mathrm{E}+07$ & 3.02 & & & $9.24 \mathrm{E}+08$ & 0.79 & 0.077 & 3.14 \\
\hline $117-130 \mathrm{~cm}$ & 13346 & 43.44 & $8.02 E+08$ & 0.57 & $6.57 \mathrm{E}+07$ & 1.70 & & & $8.67 E+08$ & 0.55 & 0.082 & 1.80 \\
\hline $130-143 \mathrm{~cm}$ & 13389 & 51.12 & $5.75 E+08$ & 0.38 & $5.59 \mathrm{E}+07$ & 1.10 & & & $6.31 \mathrm{E}+08$ & 0.36 & 0.097 & 1.17 \\
\hline $143-156 \mathrm{~cm}$ & 13345 & 58.23 & $5.35 \mathrm{E}+08$ & 3.75 & $1.01 \mathrm{E}+08$ & 4.88 & & & $6.36 \mathrm{E}+08$ & 3.25 & 0.189 & 6.16 \\
\hline \multicolumn{13}{|c|}{$\begin{array}{r}\text { Surface } \\
\text { Samples }\end{array}$} \\
\hline COC.B5 & 13344 & 68.49 & $4.57 E+08$ & 0.40 & $7.64 \mathrm{E}+07$ & 0.97 & & & $5.34 E+08$ & 0.37 & 0.167 & 1.05 \\
\hline COC.B4 & 13343 & 71.19 & $6.19 E+08$ & 0.54 & $9.65 E+07$ & 1.26 & & & $7.16 E+08$ & 0.50 & 0.156 & 1.37 \\
\hline COC.B3.5 & 13342 & 89.34 & $4.62 E+08$ & 0.32 & $7.22 E+07$ & 0.96 & & & $5.34 \mathrm{E}+08$ & 0.31 & 0.156 & 1.02 \\
\hline COC.B3 & 13348 & 49.74 & $6.12 \mathrm{E}+08$ & 3.70 & $1.79 E+08$ & 10.85 & & & $7.91 \mathrm{E}+08$ & 3.77 & $0.293^{1}$ & 11.47 \\
\hline COC.B2 & 13341 & 39.02 & $5.81 E+08$ & 0.52 & $9.24 E+07$ & 0.79 & & & $6.73 E+08$ & 0.46 & 0.159 & 0.95 \\
\hline COC.B11 & 13349 & 33.93 & $6.24 \mathrm{E}+08$ & 0.65 & $9.72 \mathrm{E}+07$ & 2.01 & $1.40 \mathrm{E}+06$ & 12.35 & $7.23 E+08$ & 0.62 & 0.156 & 2.12 \\
\hline
\end{tabular}

Uncertainties are 1 standard deviation (1 sigma) of the reported value. Values with uncertainties greater than $33 \%$ are considered to be below the minimum analytical limit of detection at the 99 percent confidence level.

${ }^{1}$ Result is not considered to be reliable; it is outside of range of atom ratios established in previous studies. 
Table 2. Plutonium Isotope Concentrations in Cochiti Reservoir Bottom Sediments

\begin{tabular}{|c|c|c|c|c|c|c|c|c|c|c|c|}
\hline \multirow[b]{2}{*}{ Sample } & \multirow{2}{*}{$\begin{array}{c}\text { Mass. } \\
\text { Spec. } \\
\text { Samp. } \\
\text { No. }\end{array}$} & \multicolumn{2}{|c|}{ Pu 239} & \multicolumn{2}{|c|}{ Pu 240} & \multicolumn{2}{|c|}{ Pu 241} & \multirow{2}{*}{$\begin{array}{c}\mathrm{Pu} \\
239+240 \\
\mathrm{pCi} / \mathrm{gm}\end{array}$} & \multicolumn{2}{|c|}{$\begin{array}{c}\text { Total Pu } \\
239+240+241\end{array}$} & \multirow{2}{*}{\begin{tabular}{|c|}
$\begin{array}{c}\text { Total Pu } \\
239+240+241\end{array}$ \\
$\mathrm{ng} / \mathrm{gm}$ \\
\end{tabular}} \\
\hline & & pCi/gm & Uncert. \% & $\mathrm{pCi} / \mathrm{gm}$ & Uncert. \% & pCi/gm & Uncert. \% & & $\mathrm{pCi} / \mathrm{gm}$ & Uncert. \% & \\
\hline \multicolumn{12}{|c|}{$\begin{array}{r}\text { Core Site } \\
\text { COC \#3 }\end{array}$} \\
\hline $\begin{array}{l}\text { COC.R11\&R12 } \\
\text { (Surface) }\end{array}$ & 13387 & 0.0130 & 0.40 & 0.0070 & 0.66 & & & 0.0199 & 0.0199 & 0.35 & $2.40 \mathrm{E}-04$ \\
\hline $0-26 \mathrm{~cm}$ & 13384 & 0.0110 & 0.51 & 0.0042 & 2.43 & & & 0.0152 & 0.0152 & 0.77 & 1.95E-04 \\
\hline $26-52 \mathrm{~cm}$ & 13385 & 0.0123 & 0.39 & 0.0038 & 1.46 & & & 0.0161 & 0.0161 & 0.46 & 2.15E-04 \\
\hline $52-78 \mathrm{~cm}$ & 13386 & 0.0402 & 0.18 & 0.0057 & 1.32 & & & 0.0459 & 0.0459 & 0.23 & 6.73E-04 \\
\hline $78-91 \mathrm{~cm}$ & 13350 & 0.0250 & 0.68 & 0.0070 & 2.32 & 0.0747 & 11.51 & 0.0320 & 0.1067 & 8.06 & 4.33E-04 \\
\hline $91-104 \mathrm{~cm}$ & 13388 & 0.0219 & 0.41 & 0.0055 & 1.60 & & & 0.0274 & 0.0274 & 0.46 & 3.77E-04 \\
\hline $104-117 \mathrm{~cm}$ & 13351 & 0.0211 & 0.81 & 0.0060 & 3.02 & & & 0.0271 & 0.0271 & 0.92 & 3.67E-04 \\
\hline $117-130 \mathrm{~cm}$ & 13346 & 0.0197 & 0.57 & 0.0059 & 1.70 & & & 0.0257 & 0.0257 & 0.59 & $3.44 \mathrm{E}-04$ \\
\hline $130-143 \mathrm{~cm}$ & 13389 & 0.0142 & 0.38 & 0.0051 & 1.10 & & & 0.0192 & 0.0192 & 0.40 & 2.51E-04 \\
\hline $143-156 \mathrm{~cm}$ & 13345 & 0.0132 & 3.75 & 0.0092 & 4.88 & & & 0.0223 & 0.0223 & 2.98 & 2.52E-04 \\
\hline \multicolumn{12}{|c|}{$\begin{array}{r}\text { Surface } \\
\text { Samples }\end{array}$} \\
\hline COC.B5 & 13344 & 0.0113 & 0.40 & 0.0069 & 0.97 & & & 0.0182 & 0.0182 & 0.44 & 2.12E-04 \\
\hline COC.B4 & 13343 & 0.0153 & 0.54 & 0.0087 & 1.26 & & & 0.0240 & 0.0240 & 0.57 & 2.84E-04 \\
\hline COC.B3.5 & 13342 & 0.0114 & 0.32 & 0.0065 & 0.96 & & & 0.0179 & 0.0179 & 0.41 & 2.12E-04 \\
\hline COC.B3 & 13348 & 0.0151 & 3.70 & 0.0162 & 10.85 & & & 0.0313 & 0.0313 & 5.90 & $3.14 \mathrm{E}-04$ \\
\hline COC.B2 & 13341 & 0.0143 & 0.52 & 0.0084 & 0.79 & & & 0.0227 & 0.0227 & 0.44 & 2.67E-04 \\
\hline COC.B11 & 13349 & 0.0154 & 0.65 & 0.0088 & 2.01 & 0.0579 & 12.35 & 0.0242 & 0.0821 & 8.72 & $2.86 \mathrm{E}-04$ \\
\hline
\end{tabular}

Uncertainties are 1 standard deviation ( 1 sigma) of the reported value. Values with uncertainties greater than $33 \%$ are considered to be below the minimum analytical limit of detection at the 99 percent confidence level ( 3 sigma). 
Table 3. Uranium Isotope Atom Ratios and Mass Concentrations in Cochiti Reservoir Bottom Sediments

\begin{tabular}{|c|c|c|c|c|c|c|c|c|c|}
\hline \multirow[b]{2}{*}{ Sample } & \multirow[b]{2}{*}{ Sample No. } & \multicolumn{2}{|c|}{ Atom Ratio } & \multicolumn{2}{|c|}{ Atom Ratio } & \multicolumn{2}{|c|}{ Atom Ratio } & \multirow{2}{*}{$\begin{array}{c}\text { Sample Size } \\
\text { gm }\end{array}$} & \multirow{2}{*}{$\begin{array}{l}\text { Total U } \\
\text { ng/gm }\end{array}$} \\
\hline & & $234 / 235$ & Uncert. \% & $236 / 235$ & Uncert. \% & $238 / 235$ & Uncert. \% & & \\
\hline \multicolumn{10}{|l|}{$\begin{array}{r}\text { Core Site } \\
\text { COC } 3 \\
\end{array}$} \\
\hline $78-91 \mathrm{~cm}$ & 13365 & 7.34E-03 & 1.52 & $-1.21 \mathrm{E}-05$ & 246.40 & $1.381 \mathrm{E}+02$ & 0.35 & 0.969 & 3765 \\
\hline $104-117 \mathrm{~cm}$ & 13381 & 7.69E-03 & 1.45 & $-8.74 E-07$ & 2595.43 & $1.376 \mathrm{E}+02$ & 0.35 & 0.962 & 3707 \\
\hline $117-130 \mathrm{~cm}$ & 13367 & $7.46 \mathrm{E}-03$ & 1.68 & 2.79E-05 & 119.42 & $1.377 \mathrm{E}+02$ & 0.53 & 1.030 & 3856 \\
\hline $143-156 \mathrm{~cm}$ & 13382 & 7.40E-03 & 1.45 & $8.28 \mathrm{E}-05$ & 30.22 & $1.376 E+02$ & 0.35 & 0.990 & 3627 \\
\hline \multicolumn{10}{|l|}{$\begin{array}{r}\text { Surface } \\
\text { Samples }\end{array}$} \\
\hline COC.B11 & 13364 & 7.30E-03 & 1.57 & $-1.32 E-05$ & 210.09 & $1.386 \mathrm{E}+02$ & 0.35 & 0.980 & 3981 \\
\hline COC.B2 & 13378 & 7.19E-03 & 1.82 & 3.70E-05 & 76.02 & $1.372 \mathrm{E}+02$ & 0.35 & 0.829 & 4123 \\
\hline$\overline{\text { COC.B3 }}$ & 13362 & 7.32E-03 & 1.68 & $-1.83 \mathrm{E}-05$ & 178.85 & $1.379 E+02$ & 0.35 & 0.862 & 4288 \\
\hline COC.B3.5 & 13379 & $7.38 \mathrm{E}-03$ & 1.67 & $-5.01 E-05$ & 49.09 & $1.375 \mathrm{E}+02$ & 0.35 & 0.923 & 3479 \\
\hline COC.B4 & 13380 & 7.34E-03 & 1.60 & $1.56 \mathrm{E}-04$ & 18.62 & $1.382 E+02$ & 0.35 & 1.011 & 3999 \\
\hline COC.B5 & 13363 & 7.43E-03 & 1.94 & $2.84 \mathrm{E}-06$ & 985.96 & $1.388 \mathrm{E}+02$ & 0.35 & 0.905 & 3799 \\
\hline
\end{tabular}

Uncertainties are 1 standard deviation ( 1 sigma) of the reported value. Values with uncertainties greater than $33 \%$ are considered to be below the minimum analytical limit of detection at the 99 percent confidence level ( 3 sigma). 
Table 4. Uranium Atom Abundances in Cochiti Reservoir Bottom Sediments

\begin{tabular}{|c|c|c|c|c|c|c|c|c|c|c|c|}
\hline \multirow[b]{2}{*}{ Sample } & \multirow{2}{*}{$\begin{array}{c}\text { Sample } \\
\text { No. }\end{array}$} & \multicolumn{2}{|c|}{ U 234} & \multicolumn{2}{|c|}{ U 235} & \multicolumn{2}{|c|}{ U 236} & \multicolumn{2}{|c|}{ U 238} & \multicolumn{2}{|c|}{$\begin{array}{c}\text { Total Uranium } \\
\text { U-234+235+236+238 }\end{array}$} \\
\hline & & Atoms/gm & Uncert. \% & Atoms/gm & Uncert. \% & Atoms/gm & Uncert. \% & Atoms/gm & Uncert. \% & Atoms/gm & Uncert. \% \\
\hline \multicolumn{12}{|l|}{$\begin{array}{r}\text { Core Site } \\
\operatorname{coc} 3\end{array}$} \\
\hline $78-91 \mathrm{~cm}$ & 13365 & $5.02 \mathrm{E}+11$ & 1.50 & $6.85 \mathrm{E}+13$ & 0.25 & $-8.3 E+08$ & -246.40 & $9.459 E+15$ & 0.25 & $9.5277 \mathrm{E}+15$ & 0.25 \\
\hline $104-117 \mathrm{~cm}$ & 13381 & $5.21 \mathrm{E}+11$ & 1.42 & $6.77 E+13$ & 0.25 & $-5.9 E+07$ & -2595.43 & $9.311 \mathrm{E}+15$ & 0.25 & $9.3789 E+15$ & 0.25 \\
\hline $117-130 \mathrm{~cm}$ & 13367 & $5.25 E+11$ & 1.64 & $7.03 E+13$ & 0.39 & $1.96 \mathrm{E}+09$ & 119.42 & $9.687 E+15$ & 0.36 & $9.7581 \mathrm{E}+15$ & 0.36 \\
\hline $143-156 \mathrm{~cm}$ & 13382 & $4.9 \mathrm{E}+11$ & 1.43 & $6.62 E+13$ & 0.25 & $5.48 \mathrm{E}+09$ & 30.22 & $9.111 E+15$ & 0.25 & $9.1778 \mathrm{E}+15$ & 0.25 \\
\hline \multicolumn{12}{|l|}{$\begin{array}{r}\text { Surface } \\
\text { Samples }\end{array}$} \\
\hline COC.B11 & 13364 & $5.27 \mathrm{E}+11$ & 1.55 & $7.22 E+13$ & 0.25 & $-9.5 E+08$ & -210.09 & $1 E+16$ & 0.25 & $1.0075 \mathrm{E}+16$ & 0.25 \\
\hline COC.B2 & 13378 & $5.42 \mathrm{E}+11$ & 1.81 & $7.55 \mathrm{E}+13$ & 0.25 & $2.79 \mathrm{E}+09$ & 76.02 & $1.036 \mathrm{E}+16$ & 0.25 & $1.0432 E+16$ & 0.25 \\
\hline COC.B3 & 13362 & $5.72 \mathrm{E}+11$ & 1.66 & $7.81 \mathrm{E}+13$ & 0.25 & $-1.4 \mathrm{E}+09$ & -178.85 & $1.077 \mathrm{E}+16$ & 0.25 & $1.0851 E+16$ & 0.25 \\
\hline COC.B3.5 & 13379 & $4.69 \mathrm{E}+11$ & 1.65 & $6.36 \mathrm{E}+13$ & 0.25 & $-3.2 E+09$ & -49.08 & $8.74 \mathrm{E}+15$ & 0.25 & $8.8035 E+15$ & 0.25 \\
\hline COC.B4 & 13380 & $5.34 E+11$ & 1.58 & $7.27 E+13$ & 0.25 & $1.13 \mathrm{E}+10$ & 18.61 & $1.005 E+16$ & 0.25 & $1.0118 \mathrm{E}+16$ & 0.25 \\
\hline COC.B5 & 13363 & $5.11 \mathrm{E}+11$ & 1.93 & $6.88 \mathrm{E}+13$ & 0.25 & $1.96 \mathrm{E}+08$ & 985.96 & $9.545 E+15$ & 0.25 & $9.6141 \mathrm{E}+15$ & 0.25 \\
\hline
\end{tabular}

Uncertainties are 1 standard deviation (1 sigma) of the reported value. Values with uncertainties greater than $33 \%$ are considered to be below the minimum analytical limit of detection at the 99 percent confidence level ( 3 sigma) 
Table 5. Uranium Isotope Concentrations in Cochiti Reservoir Bottom Sediments

\begin{tabular}{|c|c|c|c|c|c|c|c|c|c|c|c|}
\hline \multirow[b]{2}{*}{ Sample } & \multirow[b]{2}{*}{$\begin{array}{c}\text { Sample } \\
\text { No. }\end{array}$} & \multicolumn{2}{|c|}{ U 234} & \multicolumn{2}{|c|}{ U 235} & \multicolumn{2}{|c|}{ U 236} & \multicolumn{2}{|c|}{ U 238} & \multicolumn{2}{|c|}{$\begin{array}{c}\text { Total Uranium } \\
\mathrm{U}-234+235+236+238 \\
\end{array}$} \\
\hline & & pCl/gm & Uncert. \% & $\mathrm{pCi} / \mathrm{gm}$ & Uncert. \% & pCi/gm & Uncert. \% & pCi/gm & Uncert. \% & pCi/gm & $\begin{array}{l}\text { Uncert. } \\
\text { pCi/gm }\end{array}$ \\
\hline \multicolumn{12}{|l|}{$\begin{array}{r}\text { Core Site } \\
\mathrm{COC} 3\end{array}$} \\
\hline $78-91 \mathrm{~cm}$ & 13365 & 1.2126 & 1.50 & 0.0578 & 0.25 & 0.0000 & -246.40 & 1.2562 & 0.25 & 2.527 & 0.018 \\
\hline $104-117 \mathrm{~cm}$ & 13381 & 1.2567 & 1.42 & 0.0571 & 0.25 & 0.0000 & -2595.43 & 1.2365 & 0.25 & 2.550 & 0.018 \\
\hline $117-130 \mathrm{~cm}$ & 13367 & 1.2660 & 1.64 & 0.0593 & 0.39 & 0.0000 & 119.42 & 1.2865 & 0.36 & 2.612 & 0.021 \\
\hline $143-156 \mathrm{~cm}$ & 13382 & 1.1831 & 1.43 & 0.0558 & 0.25 & 0.0001 & 30.22 & 1.2100 & 0.25 & 2.449 & 0.017 \\
\hline \multicolumn{12}{|l|}{$\begin{array}{r}\text { Surface } \\
\text { Samples }\end{array}$} \\
\hline COC.B11 & 13364 & 1.2712 & 1.55 & 0.0609 & 0.25 & 0.0000 & -210.09 & 1.3283 & 0.25 & 2.660 & 0.020 \\
\hline COC.B2 & 13378 & 1.3086 & 1.81 & 0.0636 & 0.25 & 0.0001 & 76.02 & 1.3754 & 0.25 & 2.748 & 0.024 \\
\hline COC.B3 & 13362 & 1.3804 & 1.66 & 0.0659 & 0.25 & 0.0000 & -178.85 & 1.4306 & 0.25 & 2.877 & 0.023 \\
\hline COC.B3.5 & 13379 & 1.1324 & 1.65 & 0.0536 & 0.25 & -0.0001 & -49.08 & 1.1607 & 0.25 & 2.347 & 0.019 \\
\hline COC.B4 & 13380 & 1.2884 & 1.58 & 0.0613 & 0.25 & 0.0003 & 18.61 & 1.3341 & 0.25 & 2.684 & 0.021 \\
\hline COC.B5 & 13363 & 1.2334 & 1.93 & 0.0580 & 0.25 & 0.0000 & 985.96 & 1.2676 & 0.25 & 2.559 & 0.024 \\
\hline
\end{tabular}

Uncertainties are 1 standard deviation (1 sigma) of the reported value. Values with uncertainties greater than $33 \%$ are considered to be below the minimum analytical limit of detection at the 99 percent confidence level ( 3 sigma). 
one sigma level. These standard deviations propagate the errors associated with measuring the count rate of each isotope and the measurement backgrounds. Data have been corrected for processing blanks. The uncertainty associated with measurements of the processing blanks is included in the uncertainty term reported for the atom ratios. The standard deviation does not include any errors associated with sample inhomogeneity. The plutonium and uranium activity levels were determined by multiplying the number of atoms of each isotope per gram measured by TIMS by the appropriate half-life and decay constants. The uranium mass equivalent concentrations were determined by multiplying the number of atoms by the appropriate specific activities.

\section{Activity Levels}

Both the plutonium and uranium activity levels are generally consistent with levels previously reported in the Laboratory's annual Environmental Surveillance Report. In all of the samples analyzed, the plutonium and uranium activity levels are far below levels that pose a measurable risk. At the core site, the depth-weighted average ${ }^{239+240} \mathrm{Pu}$ activity level is $26 \mathrm{fCi} / \mathrm{g}$. In comparison, the mean long-term ${ }^{239+240} \mathrm{Pu}$ activity level in the Cochiti sediments collected since 1979 is $20 \mathrm{fCi} / \mathrm{g}$ (Figure 3). The Laboratory's Environmental Restoration Project currently uses a ${ }^{239+240} \mathrm{Pu}$ level of 24,000 $\mathrm{fCi} / \mathrm{g}$ as an initial check on whether a contaminant level warrants further study or remedial action. The plutonium levels in the Cochiti Lake sediments are 1000 times lower than that screening level.

Uranium levels at the core site average $2.5 \mathrm{pCi} / \mathrm{g}$. This compares favorably with the long-term annual Environmental Surveillance Report average of $2.1 \mathrm{pCi} / \mathrm{g}$ for the "Cochiti Lower" sampling station, calculated by converting the average uranium metal concentration $(3.2 \mathrm{mg} / \mathrm{kg})$ to an activity by assuming secular equilibrium for the uranium isotopes. These levels are less than 1/10th the Laboratory's Environmental Restoration Project screening level of 29 $\mathrm{pCi} / \mathrm{g}$.

\section{${ }^{240} \mathbf{P u} /{ }^{239} \mathrm{Pu}$ Atom Ratios}

The primary source of plutonium in most locations is global fallout from atmospheric testing of nuclear devices (Efurd et al. 1994). Areas surrounding the Laboratory may contain plutonium from global fallout or a mixture of Laboratory-related plutonium and global fallout. The plutonium concentrations and isotopic composition of global fallout vary from location to location. Krey et al. (1976) measured the ${ }^{240} \mathrm{Pu} /{ }^{239} \mathrm{Pu}$ atom ratio in global fallout to be 0.176 with a standard deviation of 0.014 and ranges from 0.12 to 0.21 around the world. In two separate studies, Efurd et al. (1994, 1995) measured 47 soil samples from locations in Colorado believed to be representative of global fallout. The ${ }^{240} \mathrm{Pu} /{ }^{239} \mathrm{Pu}$ atom ratios in the Colorado samples ranged from a low of $0.143 \pm 0.006$ to a high of $0.183 \pm 0.073$. Efurd et al. (1995) concluded the most representative ${ }^{240} \mathrm{Pu} /{ }^{239} \mathrm{Pu}$ atom ratio for the Denver area was $0.169 \pm 0.005$.

Studies to evaluate the range in ${ }^{240} \mathrm{Pu} /{ }^{239} \mathrm{Pu}$ atom ratios in global fallout in the Los Alamos area are not complete. Therefore, for this study we have assumed that the worldwide ${ }^{240} \mathrm{Pu} /{ }^{239} \mathrm{Pu}$ atom ratios established by Krey et al. (1976) are representative of the global fallout range at Los Alamos and at Cochiti Lake. Three ranges of atom ratios are thus used to interpret the data, assuming that the Laboratory is the only source of non-global fallout plutonium:

- Environmental samples with ${ }^{240} \mathrm{Pu} /{ }^{239} \mathrm{Pu}$ atom ratios larger than 0.16 are assumed to be dominated by global fallout plutonium. 
- Environmental samples with ${ }^{240} \mathrm{Pu} /{ }^{239} \mathrm{Pu}$ atom ratios between 0.16 and 0.12 have been possibly impacted by Laboratory plutonium.

- Environmental samples with ${ }^{240} \mathrm{Pu} /{ }^{239} \mathrm{Pu}$ atom ratios smaller than 0.12 are assumed to be conclusively impacted by Laboratory plutonium.

The ${ }^{240} \mathrm{Pu} /{ }^{239} \mathrm{Pu}$ atom ratios for the Cochiti Lake samples are listed in Table 1 and in Figure 5 compared with the ratio ranges for global fallout and for Laboratory plutonium found in Los Alamos Canyon (Gallaher et al., in preparation). The figure illustrates for each station the calculated atom ratio plus its three standard deviations uncertainty (approximate 99 percent confidence interval, three sigma). Samples with higher activities of plutonium generally yield more robust measurements of the isotopic ratios, i.e., lower uncertainties. If the upper limit of the ratio plus uncertainty is lower than the global fallout range, then the data indicate the presence of a non-fallout source of plutonium.

Figure 5 indicates that Laboratoryderived plutonium is evident in all but one of the samples collected at the core site. These samples generally reflect a mixture between global fallout plutonium and Laboratory plutonium. Most of the ${ }^{240} \mathrm{Pu} /{ }^{239} \mathrm{Pu}$ atom ratios from the core samples plot approximately midway between these sources of plutonium shown in the shaded regions in Figure 5. The initial conclusion from these data is that the plutonium in the core site sediments is approximately equally derived from global fallout and from Laboratory sources. It is unknown if the results from this core site are representative elsewhere in the lake.

In contrast to the core samples, there is minimal Laboratory plutonium in samples collected from the surface of the lake sedi- ments. The reason for this disparity is unknown at this time. A plausible explanation is the general lack of major runoff events and bedload scour in Los Alamos Canyon during recent years. Infusion of Laboratory plutonium into the main stem of the Rio Grande was largest in 1951, 1952, 1957, and 1968 according to Graf (1994). With the absence of major bedload transport from Los Alamos Canyon, there would be reduced input of Laboratory plutonium to the Rio Grande and Cochiti Lake. The isotopic composition of surficial lake bottom samples thus would tend towards global fallout signatures.

It is noteworthy that the Laboratoryderived plutonium is indicated in all of the samples with the exception of one surface sample. In addition, Laboratory-derived plutonium was detected in the core at all depths from $13-136 \mathrm{~cm}$. The Cochiti Lake study conducted by the CEPO will focus on the investigation of the areal and vertical distribution of radionuclides and other chemicals in Rio Grande sediments located both upstream and within the lake.

\section{${ }^{238} \mathbf{U} /{ }^{235} \mathbf{U}$ Atom Ratios}

The atom ratio of ${ }^{238} \mathrm{U}$ to ${ }^{235} \mathrm{U}$ in naturally occurring uranium is a constant 137.8 (Efurd et al. 1993b). The ${ }^{238} \mathrm{U} /{ }^{235} \mathrm{U}$ atom ratio in Cochiti Lake sediment samples ranged from 136.1 to 144.5. All of the samples reflect natural compositions, as shown in Figure 6. Laboratory-derived uranium is not identifiable in sediments by analysis of the ${ }^{238} \mathrm{U} /{ }^{235} \mathrm{U}$ atom ratio, presumably because the sediment contains abundant natural uranium that obscures the anthropogenic signatures.

\section{CONCLUSIONS}

The ${ }^{240} \mathrm{Pu} /{ }^{239} \mathrm{Pu}$ atom ratios confirm the presence of Laboratory-derived plutonium in the Cochiti Lake sediments. Laboratory- 


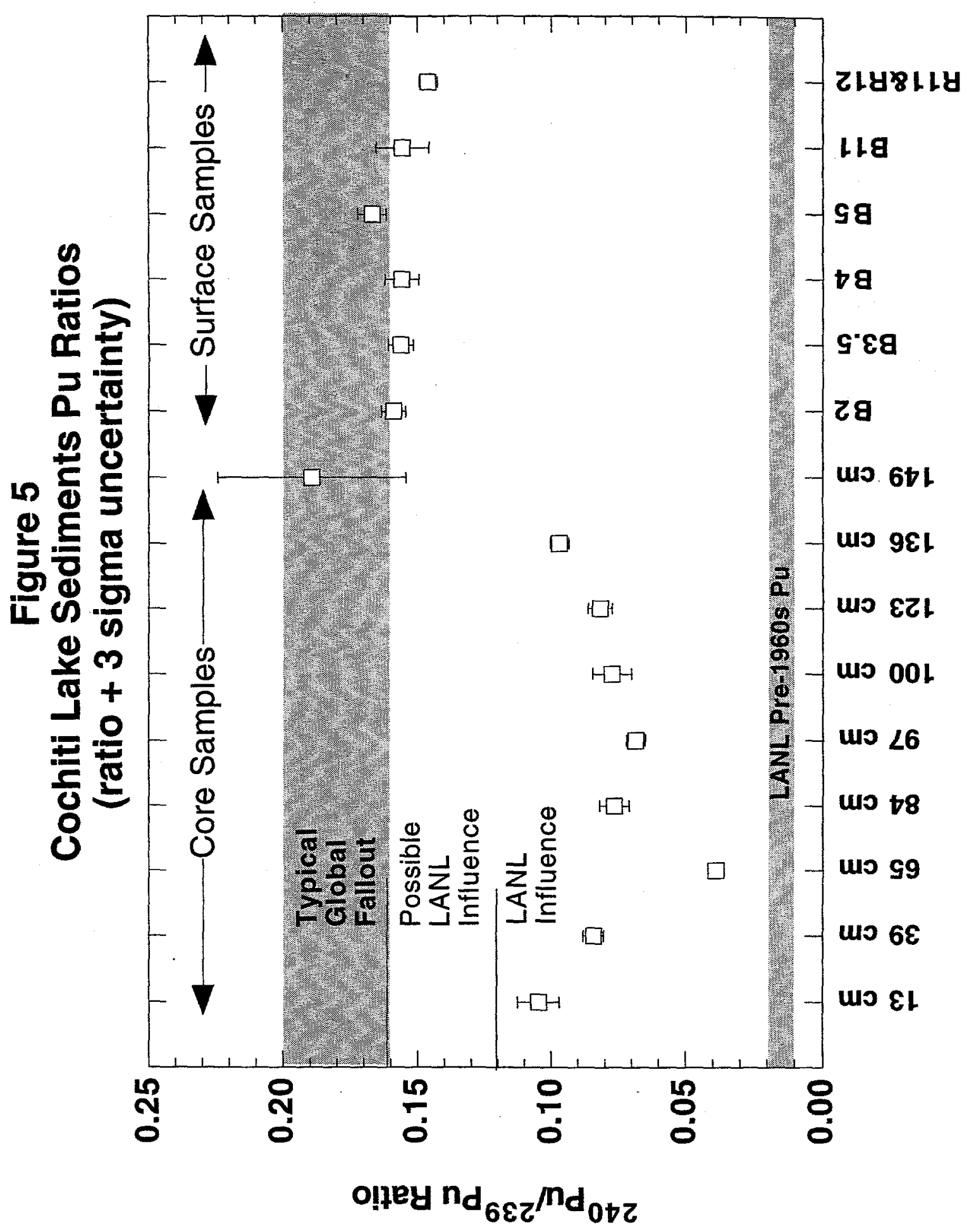

Figure 5. Cochiti Lake sediments Pu ratios. 
Figure 6

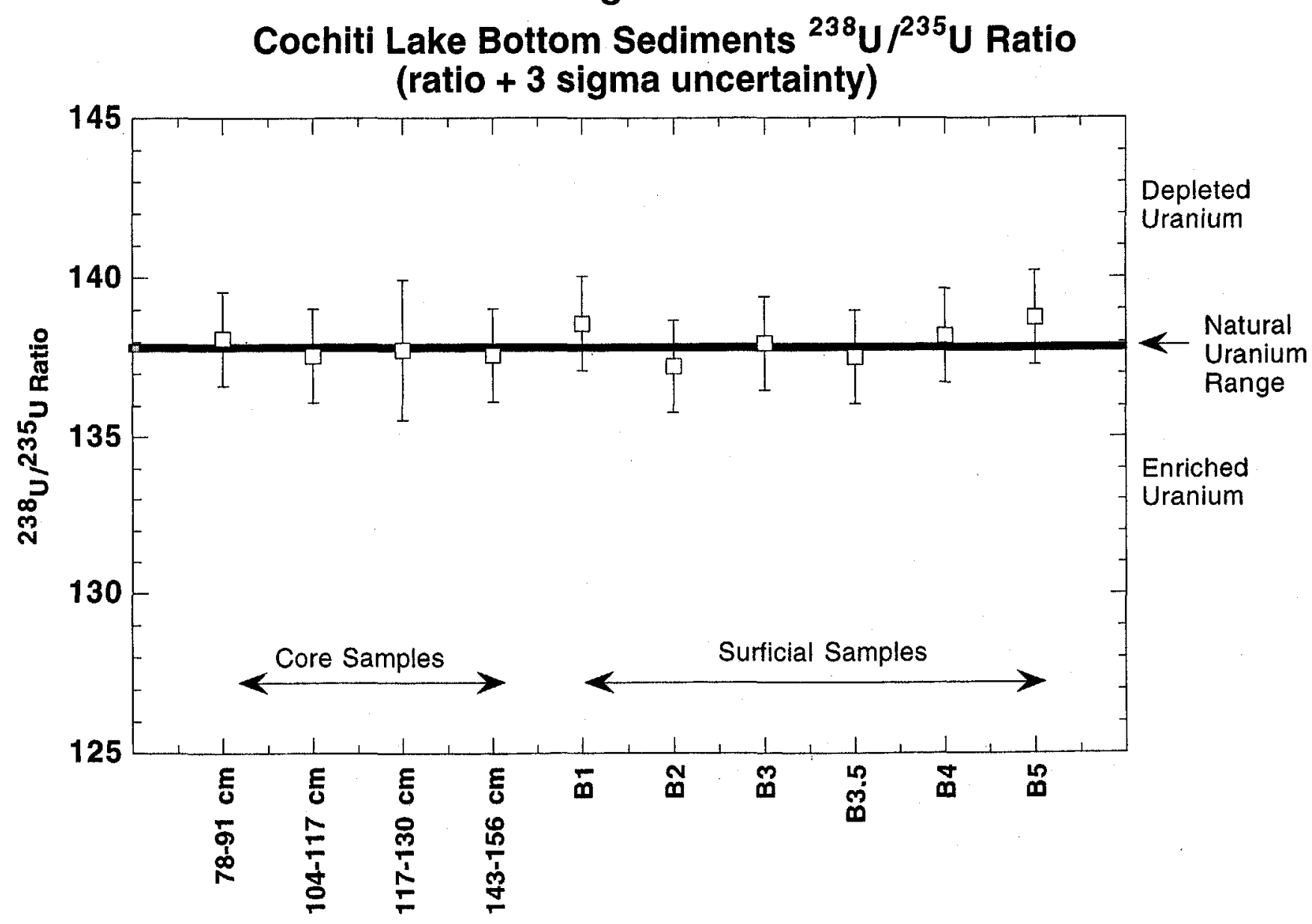


derived uranium, however, was not identifiable based on the ${ }^{238} \mathrm{U} /{ }^{235} \mathrm{U}$ atom ratios. This is evidently because sediment naturally carried into the lake by the Rio Grande contains abundant natural uranium that obscures the Laboratory signatures.

Eight of the nine segments of a vertical core taken near the dam showed clear presence of Laboratory plutonium. The ${ }^{240} \mathrm{Pu} /{ }^{239} \mathrm{Pu}$ atom ratios in the core segments tend to cluster between 0.07 to 0.10 , compared with typical ratios of 0.16 to 0.20 resulting from worldwide fallout. In contrast with the core segments taken at depth, there is minimal or no Laboratory-derived plutonium identifiable in six samples taken across the lake at the surface of the sediment pile.

On a depth-weighted basis, approximately one-half of the plutonium at the core site is derived from the Laboratory and the other half from worldwide fallout. Previous studies had estimated the Laboratory contribution to the Rio Grande drainage system to be lower -approximately 10 percent. The collected data suggest that the sediments most recently deposited in Cochiti Lake, seen at the surface of the sediment pile, are less contaminated than those at depth.

Total plutonium and uranium activity levels in all the sediments analyzed in this study are less than Screening Action Levels used by the Laboratory's Environmental Restoration Project to trigger further investigations or cleanup actions. Although a Laboratory component of plutonium is identified in the lake sediments using mass spectrometry, in most samples the net increase in radioactivity over background levels would be difficult to recognize using conventional analytical techniques.

Plutonium levels in Cochiti Lake sediments are slightly higher, but of the same magnitude, than in other upstream reservoirs. The greatest difference is seen with Abiquiu Reservoir: ${ }^{239,240} \mathrm{Pu}$ levels in Cochiti Lake are approximately $14 \mathrm{fCi} / \mathrm{g}$ $(0.014 \mathrm{pCi} / \mathrm{g})$ or 3.5 times higher. These initial isotopic fingerprinting results suggest that much of the difference can be attributed to Laboratory sources.

\section{DISCUSSION}

This study was intended to apply a new technology to help assess the Laboratory's impact on Cochiti Lake. The results of the testing show that the isotopic fingerprints of Laboratory plutonium can be identified for remarkable distances downstream. The Laboratory fingerprints are evident in most of the core segments, even though the samples were collected more than $50 \mathrm{~km}$ downstream of the Laboratory source areas and more than 30 years after the plutonium was released to the environment.

These results indicate a higher proportion of Laboratory plutonium in the lake sediments than previous studies had estimated. However, it is important to recognize that the radiological risk posed by the plutonium to aquatic life or public health appears to be relatively low by several measures. While the plutonium levels in Cochiti Lake are elevated above upstream locations, they are approximately 1000 times below levels that would generally trigger cleanup for radiological exposure concerns. In more than a decade of testing, there is no evidence of Laboratory-derived plutonium (or other radionuclides) entering the food chain or water within Cochiti Lake. Estimated radiological doses for current and assumed future land uses are low when compared to doses received from natural sources. Future Laboratory reports and Pueblo de Cochiti investigations will address this issue in more detail.

Additional coring will have to be performed to determine if conditions seen at the 
core site (near the dam) are representative of other locations of the lake. There is some indication that the proportion of Laboratoryderived plutonium may be higher at upstream sites. Long-term monitoring by the Laboratory's Environmental Surveillance Program shows that average plutonium concentrations are higher closer to the mouth of the lake than near the dam. ${ }^{239,240} \mathrm{Pu}$ levels at the Cochiti Middle station (Figure 4) are approximately twice as high as at the Cochiti Lower station ( 29 vs. $14 \mathrm{fCi} / \mathrm{g}$ ).

The characteristics of the sediment near the dam are considerably different than near the mouth of the reservoir. Texturally, the core samples are clay rich, in contrast to upstream locations that are predominantly sand and silt rich. Additionally, measurements by the U. S. Corps of Engineers show that sedimentation rates near the mouth of lake are approximately four times greater than near the dam (Gallegos, personal communication). Studies by Nyhan et al. (1976) showed that the largest plutonium inventory in the channel sediments at the Laboratory was associated with the fine sand fraction $(>105 \mathrm{~m})$. If the sands from Los Alamos Canyon have been transported to Cochiti Lake, they would tend to be preferentially located near the mouth of the lake.

The isotopic data suggests that the most recently deposited sediments at the top of the sediment pile are less contaminated than the deeper sediments. This pattern probably reflects time variability in deposition of Los Alamos plutonium rather than a reduction in contaminant source. Research by Graf $(1994,1996)$ indicates that the plutonium stored in the Los Alamos Canyon channel sediments will likely continue to be introduced to the Rio Grande in pulses for several decades. It is unlikely that future sediment contaminant concentrations will be appreciably different than those that have been historically documented. The overall plutonium inventory in Cochiti Lake, however, will gradually increase with time through added sediments from the Laboratory and from erosion of surface soils affected by worldwide fallout.

\section{ACKNOWLEDGMENTS}

The Environmental Surveillance Program of the Los Alamos National Laboratory supported this work. We would like to thank the Pueblo de Cochiti Environmental Protection Office for providing the lake sediments for analysis. Peter Van Metre of the USGS, Austin, Texas, provided valuable information on the coring methodology. Significant analytical support was received from Fred Roensch, Harold Poths, John Chamberlain, and Phil Hemberger. The report benefited greatly from the technical review of David Rogers. 


\section{REFERENCES}

Efurd, D.W., H.D. Poths, D.J. Rokop, F.R. Roensch, and R.L. Olsen, 1995. Isotopic Fingerprinting of Plutonium in Surface Soil Samples Collected in Colorado. Los Alamos National Laboratory report LAUR-95-3361.

Efurd, D.W., D.J. Rokop, and F.R. Roensch, 1994. Measurement of ${ }^{240} \mathrm{Pu} /{ }^{239} \mathrm{Pu}$ and ${ }^{241} \mathrm{Pu} /{ }^{239} \mathrm{Pu}$ Atom Ratios in Soil Representative of Global Fallout in Colorado. Los Alamos National Laboratory report LA-UR-94-4200.

Efurd, D.W., D.J. Rokop, and R.E. Perrin, 1993a. Actinide Determination and Analytical Support for Water Characterization and Treatment Studies at Rocky Flats. Los Alamos National Laboratory report LA-UR-93-917.

Efurd, D.W., D.J. Rokop, and R.E. Perrin, 1993b. Characterization of the Radioactivity in Surface-Waters and Sediments Collected at the Rocky Flats Facility. Los Alamos National Laboratory report LA-UR-93-4373.

ER (Environmental Restoration), 1997. Screening Action Levels, Los Alamos National Laboratory Environmental Restoration Project.

ESP (Environmental Surveillance Program), 1997. Environmental Surveillance and Compliance at Los Alamos during 1996. Los Alamos National Laboratory report LA-13343-ENV.

Ferenbaugh, R.W., T.E. Buhl, A.K. Stoker, N.M. Becker, J.C. Rodgers, and W.C.Hansen, 1994. Environmental Analysis of Lower Pueblo/Lower Los Alamos Canyon, Los Alamos, New
Mexico. Los Alamos National

Laboratory report LA-12857-MS.

Fresquez, P.R., D.R. Armstrong, J.G. Salazar, 1995. Radionuclide Concentrations in Soils and Produce from Cochiti, Jemez, Taos, and San Ildefonso Pueblo Gardens. Los Alamos National Laboratory report LA-12932-MS.

Fresquez, P.R., D.R. Armstrong, J.G. Salazar, 1994. Radionuclide Concentrations in Game and Nongame Fish Upstream and Downstream of Los Alamos National Laboratory: 1981 to 1993. Los Alamos National Laboratory report LA-12818-MS.

Gallaher, B.M., A.K. Stoker, D.W. Efurd, D.J. Rokop, and T.M. Benjamin, 1999. Sources of Plutonium and Uranium in the Northern Rio Grande Drainage System: Survey of Sediments and Surface Waters by Isotopic Fingerprinting. Los Alamos National Laboratory report in preparation.

Gonzales, D. 1999. US Corps of Engineers, personal communication.

Graf, W.L., 1996. Transport and Deposition of Plutonium-Contaminated Sediments by Fluvial Processes, Los Alamos Canyon, New Mexico. Geological Society of America Bulletin, Vol. 108, No. 10, pp. 1342-1355.

Graf, W.L., 1994. Plutonium and the Rio Grande: Environmental Change and Contamination in the Nuclear Age. New York: Oxford University Press.

Krey, P.W., E.P. Hardy, C. Pachucki, F. Rourke, J. Coluzza, and W.K. Benson, 1976. Mass Isotopic Composition in Global Fall-Out Plutonium in Soil. In: 
Proceedings of a Symposium on Transuranium Nuclides in the Environment, San Francisco, November 17-21, 1975, International Atomic Energy Agency, Vienna, 1976.

LANL, 1998. Evaluation of Sediment Contamination in Lower Los Alamos Canyon, Reaches LA-4 and LA-5. Los Alamos National Laboratory report LAUR-98-3975.

McLin, S., 1999. LANL ESH-18, Personal communication.

Nyhan, J.W., F.R. Miera, Jr., and R.J. Peters, 1976. Distribution of Plutonium in Soil Size Fractions of Liquid EffluentReceiving Areas at Los Alamos. Journal of Environmental Quality, v. 5, pp. $50-56$.
Purtymun, W.D., R.J. Peters, and M.N. Maes, 1990. Plutonium Deposition and Distribution from Worldwide Fallout in Northern New Mexico and Southern Colorado. Los Alamos National Laboratory report LA-11794-MS.

USDOE, 1981. Radiological Survey of the Site of a Former Radioactive Liquid Waste Treatment Plant (TA-45) and the Effluent Receiving Areas of Acid, Pueblo, and Los Alamos Canyons, Los Alamos, New Mexico. U.S. Department of Energy report DOE ENV-0005/30.

Van Metre, P.C. and E. Callender, 1997. Water-Quality Trends in White Rock Creek Basin from 1912-94 Identified Using Sediment Cores from White Rock Lake Reservoir, Dallas, Texas. Journal of Paleolimnology, v. 17, pp. 239-249. 